\title{
PENGARUH KETERAMPILAN MANAJERIAL KEPALA SEKOLAH DAN KINERJA GURU TERHADAP MUTU PENDIDIKAN
}

\author{
Firmansyah \\ Institut Agama Islam Negeri Palopo \\ E-mail: manajemen.firmansyah.90@gmail.com
}

\begin{abstract}
Abstrak
Penelitian ini bertujuan untuk mengetahui pengaruh keterampilan manajerial kepala sekolah terhadap mutu pendidikan, untuk mengetahui pengaruh kinerja guru terhadap mutu pendidikan, untuk mengetahui pengaruh keterampilan manajerial kepala sekolah dan kinerja terhadap mutu pendidikan. Penelitian ini merupakan penelitian kuantitatif dengan desain ex-post factodan berkarakteristik dekriptif kuantitatif. Jumlah populasi 67 orang dengan teknik sampling jenuh. Pengelolaan data dimulai dengan uji validitas dan uji realibilitas instrument instrumen penelitian diperoleh dengan menggunakan SPSS. Uji prasyarat meliputi uji normalitas, uji homogenitas, dan uji linieritas. Analisis akhir (uji hipotesis) menggunakan statistic analisis regresi berganda $Y=\alpha+\beta X_{1}+\beta X_{2}$ sebagai alat prediksi dalam menentukan bersarnya hubungan fungsional antara variaberl $X_{1}$ dan $X_{2}$ dengan variable $\mathrm{Y}$. Uji hipotesis menggunakan bantuan program SPSS. Hasil Uji hipotesis menunjukkan bahwa pengaruh keterampilan manajerial kepala sekolah dan kinerja guru terhadap mutu pendidikan sebesar 36,2\%. Hal ini berate bahwa 36,2\% keterampilan manajerial kepala sekolah $\left(\mathrm{X}_{1}\right)$ dan kinerja guru $\left(\mathrm{x}_{2}\right)$ berpengaruh terhadap variable mutu pendidikan $(\mathrm{Y})$ melalui hubungan linier $\mathrm{Y}=29,480+0,058+0,475$. Oleh karena itu ada pengaruh keterampilan manajerial dan kinerja guru terhadap mutu pendidikan di MTs Negeri Palopo.
\end{abstract}

Kata Kunci: Keterampilan Manajerial Kepala Sekolah, Kinerja Guru, Mutu Pendidikan

\begin{abstract}
The aims of this research are to determine the effect of principls' managerial skills on the quality of education, to know the effect of teacher performance on education quality, and to know the influence of principals' managerial skills and teacher performance on the quality of education. This research is quantitative with ex-post facto by descriptive-quantitatif characteristic. The population are 67 people with saturated sampling technique. Data processing begins with a validity test and reliability test of the research instrument is obtained using SPSS. The analisys of prerequisite test included normality, homogeneity test and linierity test. The final analysis (hypothesis testing) using statistical multiple regression analysis $Y=\alpha+\beta X_{1}+\beta X_{2}$ as a predictor in determining the magnitude of fungsional relationship between variables $X_{1}$ and $X_{2}$ with variable $Y$. Hyphothesis test using SPSS program assistance. The results of hypothesis testing indicate that the influence of principals' managerial skills and teacher performance on education quality is $36.2 \%$. It means that $36.2 \%$ of principals' managerial skill (X1) and teacher's performance (X2) influence the education quality variable (Y) through a linier relationship $Y=29.480+0.058+0.475$. therefore there is influence of principals' managerial skills and teacher's performance on the quality of education at MTs Negeri Palopo.
\end{abstract}

Keywords: Principal Managerial Skill, Teacher Performance, Education Quality 


\section{6 | Firmansyah}

\section{Pendahuluan}

Pendidikan yang baik dapat dilihat pada mutu pendidikan. Pendidikan yang bermutu harus mampu mencapai tujuan pendidikan dan mengacu pada tujuan pendidikan nasional sesuai yang Undang-Undang Sistem Pendidikan Nasional Nomor 20 tahun 2003, yaitu mengembangkan potensi peserta didik agar menjadi manusia yang beriman dan bertaqwa kepada Tuhan Yang Maha Esa, berakhlak mulia, sehat, berilmu, cakap, kreatif, dan menjadi warga Negara yang demokratis serta bertanggungjawab. ${ }^{1}$ Pendidikan yang baik mengharuskan tersedianya sumber daya manusia yang baik dalam pengelolaannya. Profesionalisme dalam bidang pengelolaan lembaga pendidikan harus menjadi prioritas.

Sekolah merupakan suatu organisasi yang kompleks. Kepala sekolah tidak hanya merupakan pemimpin (leader) di sekolahnya, tetapi juga memiliki fungsi dan tugas lebih dari sekedar memimpin suatu organisasi biasa. Keterampilan manajerial kepala sekolah sangat menentukan keberhasilan kinerja guru dan sekolah. Paradigma pendidikan yang memberikan kewenangan luas kepala sekolah dalam mengembangkan berbagai aspek manajerialnya, agar dapat mencapai tujuan sesuai dengan visi dan misi yang diemban sekolahnya. ${ }^{2}$

Wahjosumidjo menyatakan bahwa kepala sekolah adalah seorang tenaga fungsional yang diberi tugas untuk memimpin suatu sekolah yang menyelenggrakan proses pembelajaran sehingga pada hakikatnya kepala sekolah merupakan seorang perencana, organisator, penggerak, dan pengendali. ${ }^{3}$ Menurut Dirawat kepala sekolah memiliki dua tanggung jawab yaitu tugas kepala sekolah dalam bidang organisasi dan tugas kepala sekolah dalam bidang supervisi. ${ }^{4}$

Dalam menjalankan tugas pokok tersebut, kepala sekolah harus memiliki kompetensi sesuai dengan Permendiknas Nomor 13 Tahun 2007 tentang Standar Kepala Sekolah yang menyatakan bahwa kepala sekolah sekolah harus memiliki lima dimensi kompetensi yaitu kompetensi kepribadian, kompetensi manajerial, kompetensi kewirausahaan kompetensi supervisi, dan kompetensi sosial ${ }^{5}$. Kepala sekolah bekerja atas dasar prinsip kerja manajemen dengan memanfaatkan semua sumber daya sekolah termasuk manusia dan sumber daya lainnya. Kapala sekolah memaksimalkan skill yang dimilikinya untuk dapat mencapai tujuan pendidikan yang bermutu. Keterampilan (Skill) menurut Robbins dalam Soebagio Atmidiwiro merupakan kapasitas individu untuk melakukan tugas dalam berbagai

\footnotetext{
1Departemen Pendidikan Nasional, Undang-Undang Nomor 20 tahun 2003 tentang Sistem Pendidikan Nasional, (Jakarta: Depdiknas, 2004). 2006), h. 8 .

2E. Mulyasa, Menjadi Kepala Sekolah Profesional, (Bandung: Remaja Rosdakarya, 2003), h. 83.

${ }^{3}$ Wahjosumidjo, Kepemimpinan Kepala Sekolah, (Jakarta: Raja Grafindo Persada,

4Dirawat, Pengantar Kepemimpinan Pendidikan, (Jakarta: Usaha Nasional, 2006), h. 43.

5Republik Indonesia, Permendiknas Nomor 13 Tahun 2007 tentang Standar Kepala Sekolah, (Jakarta: Sekretariat Negara, 2007).
} 
pekerjaan. ${ }^{6}$ Sedangkan Yulk dalam Seobagio Atmodiwiro mengemukakan bahwa keterampilan dapat diartikan sebagai kemampuan atau skill menuju kepada kemampuan dari seseorang untuk melakukan berbagai jenis kegiatan kognitif atau diperlukan dengan suatu cara yang efektif. ${ }^{7}$ Kemampuan menggerakkan orang inilah yang kemudian dikenal dengan istilah keterampilan manajerial atau managerial skill.

Praktek manajerial adalah kegiatan yang dilakukan oleh manajer sedangkan keterampilan manajerial dapat disebut dengan kemampuan atau kecakapan manajerial yaitu suatu keterampilan atau karakteristik personal yang membantu tercapainya kinerja yang tinggi dalam tugas manajerial, serta ahli dalam menggerakkan orang lain untuk bekerja dengan baik. Siagian menyatakan bahwa keterampilan manajerial adalah keahlian menggerakkan orang lain untuk bekerja dengan baik. ${ }^{8}$

Peningkatan kualitas kepemimpinan pendidikan meliputi pengetahuan mengenai konsep (conceptual skill), keterampilan kemanusiaan (human skill) yang meliputi pengetahuan mengenai kerjasama (teamwork), hubungan antar manusia yang menuntut intelegensi interpersonal, kemampuan administrasi dan evaluasi tingkah laku. Keterampilan teknis (technical skill) meliputi pengetahuan mengenai gaya-gaya kepemimpinan yang sesuai untuk meningkatkan inisiatif dan inovasi dari petugas dan pengelola pendidikan, serta kepemimpinan yang menghidupkan partisipasi dari semua komponen yang bergerak di dalam kegiatan pendidikan. ${ }^{9}$ Pernyataan tersebut diperkuat oleh penelitian yang dilakukan oleh Thomas yang menyatakan bahwa ada tiga keterampilan efektif yaitu keterampilan teknis, keterampilan manusiawi, dan keterampilan konsep. ${ }^{10}$ Kepala sekolah sebagai manajer juga sangat memerlukan ketiga keterampilan tersebut yakni menguasai keterampilan konsep, keterampilan manusiawi, dan keteramplan teknis.

Kinerja merupakan suatu wujud perilaku seseorang atau organisasi dengan orientasi prestasi. ${ }^{11}$ Prestasi kerja atau kinerja merupakan hasil kerja secara kualitas dan kuantitas atas pencapaian seorang pegawai dalam melaksanakan tugasnya sesuai dengan tugas dan tanggung jawab yang diberikan kepadanya. ${ }^{12}$ Senada dengan Sunyono yang mengungkapkan bahwa

${ }^{6}$ Soebagio Armodiwiro, Manajemen Pendidikan Indonesia, (Jakarta: Ardadzya Jaya, 2010), h. 100.

7 Soebagio Armodiwiro, Manajemen Pendidikan Indonesia, h. 100.

${ }^{8}$ Sondang P. Siagian, Fungsi-Fungski Manajerial, (Jakarta: Bumi Aksara, 2002), h. 36.

${ }^{9}$ H.A.R. Tilaar, Permasalahan Pendidikan Indonesia, (Jakarta: Penerbit Kompas, 2004), h. 97.

${ }^{10}$ Clarence Henry Thomas, Three-Skill of Effective Administrative and Their Comfort Level in The Conduct of The Performance Evaluation of School Psychologist, Disertation, (Michigan: College of Bowling Green State Unversity, 2009), h. 93. 2008), h, 20 .

11Departemen Pendidikan Nasional, Penilaian Kinerja Guru, (Jakarta: Ditjen PMTK,

${ }^{12}$ Anwar Prabu Mangkunegara, Manajemen Sumber Daya Manusia, (Bandung: Remaja Rosdakarya, 2001), h. 67. 


\section{8 | Firmansyah}

prestasi kerja adalah suau hasil kerja yang dicapai seseorang dalam melaksanakan dan menyelesaikan pekerjaan yang dibebankan kepadanya. ${ }^{13}$

Faktor yang mempengaruhi kinerja adalah faktor kemampuan dan motivasi. Keith Davis dalam Mankunegara merumuskan kinerja dengan performance $=$ ablity and motivation, motivation=attitude and situation, ability is knowledge and skill. ${ }^{14}$ Heidjarachman faktor prestasi antara lain kualitas kerja, kuantitas kerja, kehandalan, dan sikap kerja. ${ }^{15}$ Pencapaian kinerja yang produktif perlu ditunjang oleh kemampuan kerja yang tinggi, kemampuan kerja yang sesuai, lingkungan kerja yang nyaman, penghasilan yang memenuhi kebutuhan hidup minimum, jaminan sosial yang memadai, kondisi kerja yang manusiawi dan hubungan kerja yang harmonis. ${ }^{16}$

Menurut Yamin dan Maisah menjelaskan faktor-faktor yang memengaruhi kinerja guru antara lain faktor intrinsik guru (individual) yaitu SDM dan ekstrinsik yaitu kepemimpinan, tim, dan sistem, dan situational yang diuraikan secara sebagai berikut:

1. Faktor individual, meliputi unsur pengetahuan, keterampilan, kemampuan, kepercayaan diri, motivasi, dan komitmen yang dimiliki;

2. Faktorp kepemimpinan, meliputi aspek kualitas manajer dan team leader dalam memberikan dorongan, semangat, arahan, dan dukungan kerja;

3. Faktor tim, meliputi kualitas dukungan dan semangat yang diberikan oleh rekan dalam satu tim, kepercayaan sesama anggota tim, dan kekompakan;

4. Faktor sistem, meliputi system kerja, fasilitas kerja yang diberikan oleh pimpinan sekolah, proses organisasi, kultur organisasi (sekolah);

5. Faktor kontekstual (situasional), meliputi tekanan dari perubahan lingkungan ekternal dan internal. ${ }^{17}$

Faktor pengelolaan dan faktor kinerja diharapakan bermuara pada mutu yang akan dicapai termasuk dalam konteks pendidikan. Dzaujak Ahmad menyatakan bahwa mutu pendidikan adalah kemampuan sekolah dalam pengelolaan secara operasional dan efisiensi terhadap komponen-komponen yang berkaitan dengan sekolah, sehingga menghasilkan nilai tambah terhadap komponen tersebut menurut norma atau standar yang berlaku. ${ }^{18}$ Oemar Hamalik dalam Umiarso melihat mutu pendidikan pada dua sisi yaitu dari segi normatif dimana mutu ditentukan berdasarkan pertimbangan intrinsik dan ekstrinsik. Kriteria intrinsik melihat mutu

\footnotetext{
13Danang Sunyono, Teori, Kuesioner, dan Analisis Data Sumber Daya Manusia: Praktek Penelitian, (Yogyakarta: CAPS, 2012), h. 18.

${ }^{14}$ Anwar Prabu Mangkunegara, Manajemen Sumber Daya Manusia, h. 67.

${ }^{15}$ Danang Sunyono, Teori, Kuesioner, dan Analisis Data Sumber Daya Manusia: Praktek Penelitian, h. 18.

${ }^{16}$ Tjutju Yuniarsih dan Suwatno, Manajemen Sumber Daya Manusia:Teori, APlikasi, dan Isu Penenitian, (Bandung: Alfabeta, 2008), h. 161.

17Martinis Yamin dan Maisah, Standarisasi Kinerja Guru, (Jakarta: GP Press, 2010), h. 129.

18Umiarso dan Imam Gojali, Manajemen Mutu Sekolah di Era Otonomi Pendidikan, (Jogjakarta: IRCiSod, 2010), h. 220.
} 
pendidikan sebagai produk pendidikan yakni manusia yang terdidik sesuai dengan standar ideal sedangkan kriteria ekstrinsik melihat pendidikan sebagai tenaga kerja terlatih. Dalam arti deskriptif, mutu pendidikan ditentukan berdasarkan keadaan senyatanya, seperti hasil test prestasi belajar. ${ }^{19}$

Penelitian yang dilakukan oleh Agustina menyimpulkan bahwa kepemimpinan kepala sekolah, iklim sekolah dan kinerja guru berpengaruh secara langsung terhadap mutu pendidikan. ${ }^{20}$ Penelitiaa Irma Angraeni merekomendasikan bahwa kepala sekolah dapat meningkatkan kinerja manajerialnya, khususnya dalam kemampuan pengambilan keputusan yang tepat dan para guru bisa memperbaiki kinerja mengajarnya dengan menambah pengetahuan, wawasan, dan keilmuannya khususnya dalam pelaksanaan proses belajar mengajar guna mewujudkan pembelajaran yang efektif. ${ }^{21}$

Fokus penelitian ini membahas tentang pengaruh keterampilan manajerial kepala sekolah, dan kinerja guru terhadap mutu pendidikan. Adapun tujuan penelitian ini yakni 1) untuk mengetahui pengaruh keterampilan manajerial kepala sekolah terhadap mutu pendidikan di MTs Negeri Palopo, 2) untuk mengetahui pengaruh kinerja guru terhadap mutu pendidikan di MTs Negeri Palopo, dan 3) untuk mengetahui pengaruh keterampilan menajerial kepala sekolah dan kinerja guru terhadap mutu pendidikan di MTs Negeri Palopo. Penelitian ini diharapkan memberikan informasi dan pengetahuan bagi kepala sekolah dan guru mengenai keterampilan mengajar dan kinerja guru yang dapat meningkatkan mutu pendidikan.

\section{Metode}

Jenis penelitian ini adalah penelitian kuantitatif dengan desain ex-post facto. Karaktereistik penelitian ini adalah deskriptif kiantitatif. Populasi berjumlah 67 orang dengan teknik sampling jenuh. Pengelolaan data dimulai dengan uji validitas dan uji realibilitas instrument diperoleh dengan mengunakan SPSS. Selanjutnya, dilakukan uji prasyarat analisis meliputi uji normalitas, uji homogenitas, dan uji linieritas. Langkah selanjutnya adalah analisis akhir (uji hipotesis) menggunakan statistic analisis regresi berganda $\mathrm{Y}=\alpha+\beta \mathrm{X}_{1}+\beta \mathrm{X}_{2}$ sebagai alat prediksi dalam menentukan bersarnya

19Umiarso dan Imam Gojali, Manajemen Mutu Sekolah di Era Otonomi Pendidikan, h. 124.

${ }^{20}$ Agustina, Pengaruh Kepemimpina Kepala Sekolah, Iklim Sekolah, dan Kinerja Guru terhdap Mutu Pendidikan di SMP Negeri Kecamatan Terbanggi Besar Kabupaten Lampung Tengah, (Tesis, Bandar Lampung: Pascasarjana Universitas Lampung, 2016), h. 120.

21Irma Anggraeni, Kinerja Manajerial Kepala Sekolah, Kinerja Mengajar Guru dan Mutu Sekolah Dasar, (Jurnal Administrasi Pendidikan, Vol. XXIII, Nomor 2, Bandung, 2016), h. 134. 
20 | Firmansyah

hubungan fungsional antara variaberl $\mathrm{X}_{1}$ dan $\mathrm{X}_{2}$ dengan variable $\mathrm{Y}$. Uji hipotesis menggunakan bantuan program SPSS.

\section{Pengaruh Keterampilan Manajerial Kepala Sekolah terhadap Mutu Pendidikan di MTs Negeri Palopo}

Hasil analisis pengujian hipotesis dilakukan dengan mencari pengaruh keterampilan manajerial kepala sekolah $\left(\mathrm{X}_{1}\right)$ terhadap mutu pendidikan $(\mathrm{Y})$ pada MTs Negeri Palopo. Hal ini dilakukan dengan menggunakan pengolahan data melalui program SPSS versi 20 for windows sebagai berikut:

Tabel 1: Hasil Analisis Regresi Sederhana Keterampilan Manajerial Kepala Sekolah terhadap Mutu Pendidikan

Coefficients $^{\mathrm{a}}$

\begin{tabular}{|c|c|c|c|c|c|c|}
\hline \multirow[t]{2}{*}{ Model } & & \multicolumn{2}{|c|}{$\begin{array}{c}\text { Unstandardized } \\
\text { Coefficients }\end{array}$} & $\begin{array}{c}\text { Standardized } \\
\text { Coefficients }\end{array}$ & \multirow[t]{2}{*}{$\mathrm{t}$} & \multirow[t]{2}{*}{ Sig. } \\
\hline & & B & Std. Error & Beta & & \\
\hline & (Constant) & 40,170 & 5,139 & & 7,816 & ,000 \\
\hline 1 & $\begin{array}{l}\text { Keterampilan_Mana } \\
\text { jerial_Kepsek }\end{array}$ &, 371 & ,077 &, 511 & 4,795 & ,000 \\
\hline
\end{tabular}

a. Dependent Variable: Mutu_Pendidikan

Sumber: Data penelitian pada lampiran

Berdasarkan tabel analisis regresi sederhana terhadap data skor mutu pendidikan $(\mathrm{Y})$ dan keterampilan manajerial kepala sekolah $\left(\mathrm{X}_{1}\right)$ menghasilkan konstanta $\alpha$ sebesar 40,170 dan koefisien regresi $\beta X_{1}$ sebesar 0,371 sehingga persamaan regresinya yaitu: $Y=\alpha+\beta X_{1}$ atau $Y=40,170+$ 0,371 . Pengaruh antara keterampilan manajerial kepala sekolah $\left(\mathrm{X}_{1}\right)$ dan mutu pendidikan (Y) dapat disimpulkan melalui persamaan regresi $\mathrm{Y}=$ $40,170+0,371$. Persamaan regresi menunjukkan kenaikan setiap satu skor pada keterampilan manajerial kepala sekolah $\left(\mathrm{X}_{1}\right)$ menyebabkan kenaikan sebesar 0,371 pada skor hasil mutu pendidikan (Y). Pengujian tingkat signifikasi $\alpha=5 \%$, yang berarti bahwa untuk mengambil keputusan untuk menolak hipotesa yang benar sebesar $5 \%$ atau 0,05 . Dengan menggunakan taraf signifikansi yaitu peluang kesalahan 5\% dan kepercayaan 95\%. Adapun hasil analisis melalui tabel model summary menunjukkan koefisien perolehan nilai determinan sebagai berikut.

Tabel 2: Hasil Koefisien Determinasi Keterampilan Manajerial Kepala Sekolah terhadap Mutu Pendidikan

Model Summary

\begin{tabular}{|l|c|r|r|r|r|r|r|r|r|}
\hline Model & $\mathrm{R}$ & \multirow{2}{*}{$\mathrm{R}$} \\
\end{tabular}

a. Predictors: (Constant), Keterampilan_Manajerial_Kepsek

Sumber: Data penelitian pada lampiran

Kelola: Journal of Islamic Education Management 
Berdasarkan tabel di atas, analisis regresi sederhana terhadap aspek keterampilan manajerial kepala sekolah $\left(\mathrm{X}_{1}\right)$ dan mutu pendidikan (Y) menunjukkan koefisien korelasi $\mathrm{R}$ sebesar 0,511. Hasil pengujian menunjukkan koefisien regresi dengan menggunakan uji t diperoleh bahwa $t_{\text {hitung }}=7,816$ signifikan pada taraf nyata 0,000. Adapun $t_{\text {tabel }}$ pada taraf signifikansi 0,05 dengan $n=67$ maka df $=n-2$ yaitu 67-2 $=65$. Berdasarkan tabel distribusi $\mathrm{T}$, nilai $\mathrm{t}_{\text {tabel }}=1,996$. Dengan demikian dapat disimpulkan bahwa $t_{\text {hitung }} 7,816 \geq t_{\text {tabel }} 1,996$ dengan $\alpha=0,05$ sehingga $\mathrm{H}_{0}$ ditolak dan $\mathrm{H}_{1}$ diterima. Hal ini berarti bahwa ada pengaruh aspek keterampilan manajerial kepala sekolah $\left(\mathrm{X}_{1}\right)$ terhadap mutu pendidikan (Y). Pengaruh antara keterampilan manajerial kepala sekolah $\left(\mathrm{X}_{1}\right)$ terhadap mutu pendidikan (Y) didukung oleh koefisien $\mathrm{R}^{2}$ (R Square) sebesar 0,261 yang menunjukkan bahwa terdapat pengaruh signifikan antara aspek keterampilan manajerial kepala sekolah $\left(\mathrm{X}_{1}\right)$ terhadap mutu pendidikan $(\mathrm{Y})$ didukung oleh koefisien determinasi sebesar 26,1\%. Hal ini berarti bahwa $26,1 \%$ keterampilan manajerial kepala sekolah $\left(\mathrm{X}_{1}\right)$ berpengaruh terhadap variabel mutu pendidikan (Y) yang dijelaskan oleh melalui persamaan regresi $\mathrm{Y}=40,170+0,371$

\section{Pengaruh Kinerja Guru terhadap Mutu Pendidikan di MTs Negeri Palopo}

Hasil analisis pengujian hipotesis dilakukan dengan mencari pengaruh kinerja guru $\left(\mathrm{X}_{2}\right)$ terhadap mutu pendidikan (Y) pada MTs Negeri Palopo. Hal ini dilakukan sama dengan langkah-langkah sebelumnya pada pengujian variabel keterampilan manajerial kepala sekolah $\left(\mathrm{X}_{1}\right)$ terhadap mutu pendidikan (Y) pada MTs Negeri Palopo yaitu dengan menggunakan pengolahan data melalui program SPSS (Statistical Product and Service Solution) versi 20 for windows sebagai berikut.

Tabel 3: Hasil Analisis Regresi Sederhana Kinerja guru terhadap Mutu

\section{Pendidikan}

Coefficients $^{\text {a }}$

\begin{tabular}{|c|c|c|c|c|c|}
\hline \multirow[t]{2}{*}{ Model } & \multicolumn{2}{|c|}{$\begin{array}{c}\text { Unstandardized } \\
\text { Coefficients }\end{array}$} & $\begin{array}{l}\text { Standardized } \\
\text { Coefficients }\end{array}$ & $\mathrm{t}$ & Sig. \\
\hline & B & Std. Error & Beta & & \\
\hline $\begin{array}{ll}1 & \text { (Constant) } \\
& \text { Kinerja_Guru }\end{array}$ & $\begin{array}{r}29,541 \\
, 532\end{array}$ & $\begin{array}{r}5,843 \\
, 088\end{array}$ & 599 & $\begin{array}{l}5,056 \\
6,037\end{array}$ & $\begin{array}{l}, 000 \\
, 000\end{array}$ \\
\hline
\end{tabular}

a. Dependent Variable: Mutu_Pendidikan

Sumber: Data penelitian pada lampiran

Berdasarkan tabel analisis regresi sederhana terhadap data skor mutu pendidikan $(\mathrm{Y})$ dan kinerja guru $\left(\mathrm{X}_{2}\right)$ menghasilkan konstanta $\alpha$ sebesar 29,541 dan koefisien regresi $\beta X_{1}$ sebesar 0,532 sehingga persamaan regresinya yaitu: $\mathrm{Y}=\alpha+\beta \mathrm{X}_{2}$ atau $\mathrm{Y}=29,541+0,532$. Hal ini menunjukkan antara kinerja guru $\left(\mathrm{X}_{2}\right)$ dan mutu pendidikan $(\mathrm{Y})$ dapat disimpulkan melalui persamaan regresi $Y=29,541+0,532$ menunjukkan kenaikan setiap satu skor pada kinerja guru $\left(\mathrm{X}_{2}\right)$ menyebabkan kenaikan sebesar 0,532 pada skor hasil mutu pendidikan (Y). Pengujian tingkat signifikasi $\alpha=5 \%$, yang berarti 


\section{2 | Firmansyah}

bahwa untuk mengambil keputusan untuk menolak hipotesa yang benar sebesar $5 \%$ atau 0,05 . Adapun hasil analisis melalui tabel model summary menunjukkan koefisien perolehan nilai determinan sebagai berikut:

Tabel 4: Hasil Koefisien Determinasi Kinerja guru terhadap Mutu Pendidikan

Model Summary

\begin{tabular}{|c|c|c|c|c|c|c|c|c|c|}
\hline \multirow[t]{2}{*}{ Model } & \multirow[t]{2}{*}{$\mathrm{R}$} & \multirow{2}{*}{$\begin{array}{c}\mathrm{R} \\
\text { Square }\end{array}$} & \multirow{2}{*}{$\begin{array}{l}\text { Adjusted } \\
\text { R Square }\end{array}$} & \multirow{2}{*}{$\begin{array}{l}\text { Std. Error } \\
\text { of the } \\
\text { Estimate }\end{array}$} & \multicolumn{5}{|c|}{ Change Statistics } \\
\hline & & & & & $\begin{array}{c}\mathrm{R} \\
\text { Square } \\
\text { Change }\end{array}$ & $\begin{array}{c}\mathrm{F} \\
\text { Change }\end{array}$ & df1 & df 2 & $\begin{array}{c}\text { Sig. F } \\
\text { Change }\end{array}$ \\
\hline 1 &, $599^{\mathrm{a}}$ & 359 & ,349 & 2,59697 & ,359 & 36,446 & 1 & 65 & 000 \\
\hline
\end{tabular}

a. Predictors: (Constant), Kinerja_Guru

Sumber: Data penelitian pada lampiran

Berdasarkan tabel di atas, analisis regresi sederhana terhadap aspek kinerja guru $\left(\mathrm{X}_{2}\right)$ dan mutu pendidikan $(\mathrm{Y})$ menunjukkan koefisien korelasi $\mathrm{R}$ sebesar 0,599. Hasil pengujian menunjukkan koefisien regresi dengan menggunakan uji t diperoleh bahwa thitung $=5,056$ signifikan pada taraf nyata 0,000 . Adapun $t_{\text {tabel }}$ pada taraf signifikansi 0,05 dengan $n=67$ maka $\mathrm{df}=\mathrm{n}-2$ yaitu $67-2=65$. Jadi, nilai $t_{\text {tabel }}=1,996$. Dengan demikian dapat disimpulkan bahwa thitung $5,056 \geq t_{\text {tabel }} 1,996$ dengan $\alpha=0,05$ sehingga $\mathrm{H}_{0}$ ditolak dan $\mathrm{H}_{1}$ diterima. Hal ini berarti bahwa ada pengaruh aspek kinerja guru $\left(\mathrm{X}_{2}\right)$ terhadap mutu pendidikan (Y). Pengaruh antara kinerja guru $\left(\mathrm{X}_{2}\right)$ terhadap mutu pendidikan (Y) didukung oleh koefisien $\mathrm{R}^{2}$ (R Square) sebesar 0,359 yang menunjukkan bahwa terdapat pengaruh signifikan antara aspek kinerja guru $\left(\mathrm{X}_{2}\right)$ terhadap mutu pendidikan $(\mathrm{Y})$ didukung oleh koefisien determinasi sebesar 35,9\%. Hal ini berarti bahwa 35,9\% kinerja guru $\left(\mathrm{X}_{2}\right)$ berpengaruh terhadap variabel mutu pendidikan (Y) yang dijelaskan melalui persamaan regresi $Y=29,541+0,532$.

\section{Pengaruh Keterampilan Manajerial Kepala Sekolah dan Kinerja Guru terhadap Mutu Pendidikan di MTs Negeri Palopo}

Hasil analisis pengujian hipotesis dilakukan dengan mencari pengaruh keterampilan manajerial kepala sekolah $\left(\mathrm{X}_{1}\right)$ dan kinerja guru $\left(\mathrm{X}_{2}\right)$ terhadap mutu pendidikan (Y) pada MTs Negeri Palopo. Hal ini dilakukan dengan langkah-langkah yang sama sebelumnya pada pengujian variabel-variabel sebelumnya yaitu dengan menggunakan pengolahan data melalui program SPSS (Statistical Product and Service Solution) versi 20 for windows. Adapun hasilnya adalah sebagai berikut. 
Tabel 5: Hasil Analisis Regresi Berganda Keterampilan Manajerial Kepsek dan Kinerja Guru terhadap Mutu Pendidikan Coefficients $^{\mathrm{a}}$

\begin{tabular}{|c|c|c|c|c|c|c|}
\hline \multirow{2}{*}{\multicolumn{2}{|c|}{ Model }} & \multicolumn{2}{|c|}{$\begin{array}{l}\text { Unstandardized } \\
\text { Coefficients }\end{array}$} & $\begin{array}{l}\text { Standardized } \\
\text { Coefficients }\end{array}$ & \multirow[t]{2}{*}{$\mathrm{t}$} & \multirow[t]{2}{*}{ Sig. } \\
\hline & & B & Std. Error & Beta & & \\
\hline \multirow{3}{*}{1} & (Constant) & 29,480 & 5,879 & & 5,014 &, 000 \\
\hline & $\begin{array}{l}\text { Keterampilan_Manaje } \\
\text { rial_Kepsek }\end{array}$ & ,058 &, 122 & ,081 & ,478 & ,634 \\
\hline & Kinerja_Guru & ,475 &, 150 & ,534 & 3,170 & ,002 \\
\hline
\end{tabular}

a. Dependent Variable: Mutu_Pendidikan

Sumber: Data penelitian pada lampiran

Berdasarkan tabel analisis regresi berganda terhadap data skor mutu pendidikan (Y), keterampilan manajerial kepala sekolah $\left(\mathrm{X}_{1}\right)$ dan kinerja guru $\left(\mathrm{X}_{2}\right)$ menghasilkan konstanta $\alpha$ sebesar 29,480 dan koefisien regresi $\beta \mathrm{X}_{1}$ sebesar 0,058 dan $\beta X_{2}$ sebesar 0,475 sehingga persamaan regresinya yaitu: $Y$ $=\alpha+\beta X_{1}+\beta X_{2}$ atau $Y=29,480+0,058+0,475$. Hal ini menunjukkan antara keterampilan manajerial kepala sekolah $\left(\mathrm{X}_{1}\right)$ dan kinerja guru $\left(\mathrm{X}_{2}\right)$ terhadap mutu pendidikan (Y) menunjukkan kenaikan setiap satu skor pada keterampilan manajerial kepala sekolah $\left(\mathrm{X}_{1}\right)$ menyebabkan kenaikan sebesar 0,058 pada skor hasil mutu pendidikan (Y) dan kinerja guru (X $\left.\mathrm{X}_{2}\right)$ menyebabkan kenaikan sebesar 0,475 pada skor hasil mutu pendidikan (Y).

Pengujian tingkat signifikasi $\alpha=5 \%$, yang berarti bahwa untuk mengambil keputusan untuk menolak hipotesa yang benar sebesar 5\% atau 0,05 . Adapun hasil analisis melalui tabel model summary menunjukkan koefisien perolehan nilai determinan sebagai berikut.

\section{Tabel 6: Hasil Koefisien Determinasi Keterampilan Manajerial Kepsek dan Kinerja Guru terhadap Mutu Pendidikan \\ Model Summary}

\begin{tabular}{|c|c|c|c|c|c|c|c|c|c|}
\hline \multirow[t]{2}{*}{ Model } & \multirow[t]{2}{*}{$\mathrm{R}$} & \multirow{2}{*}{$\begin{array}{c}\mathrm{R} \\
\text { Square }\end{array}$} & \multirow{2}{*}{$\begin{array}{l}\text { Adjusted } \\
\text { R Square }\end{array}$} & \multirow{2}{*}{$\begin{array}{l}\text { Std. Error } \\
\text { of the } \\
\text { Estimate }\end{array}$} & \multicolumn{5}{|c|}{ Change Statistics } \\
\hline & & & & & $\begin{array}{c}\text { R } \\
\text { Square } \\
\text { Change }\end{array}$ & $\begin{array}{c}\mathrm{F} \\
\text { Change }\end{array}$ & df1 & $\mathrm{df} 2$ & $\begin{array}{c}\text { Sig. F } \\
\text { Change }\end{array}$ \\
\hline 1 &, $601^{\mathrm{a}}$ &, 362 & ,342 & 2,61253 & ,362 & 18,121 & 2 & 64 &, 000 \\
\hline
\end{tabular}

a. Predictors: (Constant), Kinerja_Guru, Keterampilan_Manajerial_Kepsek

Sumber: Data penelitian pada lampiran

Berdasarkan tabel di atas, analisis regresi berganda terhadap aspek keterampilan manajerial kepala sekolah $\left(\mathrm{X}_{1}\right)$ dan kinerja guru $\left(\mathrm{X}_{2}\right)$ dan mutu pendidikan (Y) menunjukkan koefisien korelasi $\mathrm{R}$ sebesar 0,601. Hasil pengujian menunjukkan koefisien regresi dengan menggunakan uji $t$ diperoleh bahwa $t_{\text {hitung }}=5,014$ signifikan pada taraf nyata 0,000 . Adapun $t_{\text {tabel }}$ pada taraf signifikansi 0,05 dengan $n=67$ maka $\mathrm{df}=\mathrm{n}-2$ yaitu 67-2 $=65$. Jadi, nilai $t_{\text {tabel }}=1,996$. Dengan demikian dapat disimpulkan bahwa $t_{\text {hitung }} 5,014 \geq$ $t_{\text {tabel }}$ 1,996 dengan $\alpha=0,05$ sehingga $\mathrm{H}_{0}$ ditolak dan $\mathrm{H}_{1}$ diterima. Hal ini berarti bahwa ada pengaruh aspek keterampilan manajerial kepala sekolah 


\section{4 | Firmansyah}

$\left(\mathrm{X}_{1}\right)$ dan kinerja guru $\left(\mathrm{X}_{2}\right)$ terhadap mutu pendidikan $(\mathrm{Y})$. Pengaruh antara keterampilan manajerial kepala sekolah $\left(\mathrm{X}_{1}\right)$ dan kinerja guru $\left(\mathrm{X}_{2}\right)$ terhadap mutu pendidikan $(Y)$ didukung oleh koefisien $R^{2}$ (R Square) sebesar 0,362 yang menunjukkan bahwa terdapat pengaruh signifikan antara aspek keterampilan manajerial kepala sekolah $\left(\mathrm{X}_{1}\right)$ dan kinerja guru $\left(\mathrm{X}_{2}\right)$ terhadap mutu pendidikan (Y) didukung oleh koefisien determinasi sebesar 36,2\%. Hal ini berarti bahwa 36,2\% keterampilan manajerial kepala sekolah $\left(\mathrm{X}_{1}\right)$ dan kinerja guru $\left(\mathrm{X}_{2}\right)$ berpengaruh terhadap variabel mutu pendidikan $(\mathrm{Y})$ yang dijelaskan melalui persamaan regresi $Y=29,480+0,058+0,475$.

\section{Kesimpulan}

Terdapat pengaruh positif keterampilan manajerial kepala sekolah dan kinerja guru terhadap mutu pendidikan. Hasil nilai analisis keterampilan manajerial kepala sekolah dan kinerja guru terhadap mutu pendidikan menunjukkan nilai positif. Semakin meningkat kualitas keterampilan manajerial kepala sekolah dan kinerja guru maka semakin meningkat pula mutu pendidikan.

Untuk meningkatan mutu pendidikan yang berkelanjutan maka disarankan peningkatan keterampilan kepala sekolah dan peningkatan kinerja guru baik melalui pelatihan maupun peningkatan intensitas pembinaan MGMP untuk pengembangan kinerja guru. Kerjasama antara komponen sekolah perlu untuk ditingkatkan sehingga mutu pendidikan yang tinggi bias tercapai secara maksimal.

\section{Daftar Pustaka}

Agustina. 2016. Pengaruh Kepemimpina Kepala Sekolah, Iklim Sekolah, dan Kinerja Guru terhdap Mutu Pendidikan di SMP Negeri Kecamatan Terbanggi Besar Kabupaten Lampung Tengah, Tesis, Bandar Lampung: Pascasarjana Universitas Lampung.

Anggraeni. Irma. 2016. Kinerja Manajerial Kepala Sekolah, Kinerja Mengajar Guru dan Mutu Sekolah Dasar, Jurnal Administrasi Pendidikan, Vol. XXIII, Nomor 2, Bandung.

Armodiwiro. Soebagio. 2010. Manajemen Pendidikan Indonesia, Jakarta: Ardadzya Jaya.

Departemen Pendidikan Nasional. 2004. Undang-Undang Nomor 20 tahun

2003 tentang Sistem Pendidikan Nasional, Jakarta: Depdiknas.

Departemen Pendidikan Nasional. 2008. Penilaian Kinerja Guru, Jakarta: Ditjen PMTK.

Dirawat. 2006. Pengantar Kepemimpinan Pendidikan, Jakarta: Usaha Nasional Mangkunegara. Anwar Prabu. 2001. Manajemen Sumber Daya Manusia, Bandung: Remaja Rosdakarya.

Mulyasa. E. 2006. Menjadi Kepala Sekolah Profesional, Bandung: Remaja Rosdakarya. 
Republik Indonesia. 2007. Permendiknas Nomor 13 Tahun 2007 tentang Standar Kepala Sekolah, Jakarta: Sekretariat Negara.

Siagian. Sondang P., 2002. Fungsi-Fungski Manajerial, Jakarta: Bumi Aksara.

Sunyono. Danang, 2012. Teori, Kuesioner, dan Analisis Data Sumber Daya Manusia: Praktek Penelitian, Yogyakarta: CAPS.

Thomas. Clarence Henry. 2009. Three-Skill of Effective Administrative and Their Comfort Level in The Conduct of The Performance Evaluation of School Psychologist, Disertation, Michigan: College of Bowling Green State Unversity.

Tilaar. H.A.R., 2004. Permasalahan Pendidikan Indonesia, Jakarta: Penerbit Kompas.

Umiarso dan Imam Gojali. 2010. Manajemen Mutu Sekolah di Era Otonomi Pendidikan, Jogjakarta: IRCiSod.

Wahjosumidjo. 2003. Kepemimpinan Kepala Sekolah, Jakarta: Raja Grafindo Persada.

Yamin. Martinis dan Maisah. 2010. Standarisasi Kinerja Guru, Jakarta: GP Press.

Yuniarsih. Tjutju dan Suwatno. 2008. Manajemen Sumber Daya Manusia:Teori, APlikasi, dan Isu Penenitian, Bandung: Alfabeta. 
26 | Firmansyah

HALAMAN INI SENGAJA DIKOSONGKAN 